\title{
An Efficient and Securable Networked Voting System based on Blockchain
}

\author{
R.Karthik, D.Sabarinaveenkumar, S.Santhosh Kumar, G.Srinivasan
}

\begin{abstract}
Modern period of trend setting innovation where online framework supports work speed, lessens botches and advances the age of exact outcomes, having manual political decision framework turns into a mishap. An open political decision framework establishes the foundation of a vote based system where the individuals need to choose their state's chief. India as of now utilizes a manual political decision framework, which causes a few sorts of issues. Because of this paper polling form based political race framework, a few issues are looked by voters previously or during races and others are looked by the organization when the democratic. An online framework, which includes strategies like enlistment of voters, vote throwing, vote tallying, and announcing results would comprise a decent answer for supplant current framework and the proposed framework right now be useful for the voters by utilizing any assets like their own framework or masterminded by Government. Additionally, the proposed framework will likewise diminish the hazard for defilement. The framework is proposed subsequent to talking authorities of two offices, the Country Database and Enrollment Authority India (NADRA) and the Political decision Commission of India (ECP). NADRA has an online database of the residents of India, and is giving the Modernized National Personality Cards (CNIC) and furthermore supporting various associations with their online framework. Along these lines, by utilizing NADRA's framework it turns out to be anything but difficult to enroll all voters of the age above 18, and besides to check and verify their information
\end{abstract}

Keywords: Authority, Database, Democratic, Framework, Political.

\section{INTRODUCTION}

In this a majority rules of government, the electorate will communicates through the appointment of delegates. These chosen delegates work for the nation, in the interest of the politic body. All together for the agents to suitably speak and

Revised Manuscript Received on April 27, 2020.

* Correspondence Author

Mr.R.Karthik*, Department of Computer Science and Engineering, Sri Krishna College of Technology, Coimbatore, India. Email: hpdkarthik@gmail.com

D.Sabarinaveenkumar, Department of Computer Science and Engineering, Sri Krishna College of Technology, Coimbatore, India.

S.Santhosh Kumar, Department of Computer Science and Engineering, Sri Krishna College of Technology, Coimbatore, India.

G.Srinivasan, Department of Computer Science and Engineering, Sri Krishna College of Technology, Coimbatore, India.

(c) The Authors. Published by Blue Eyes Intelligence Engineering and Sciences Publication (BEIESP). This is an open access article under the CC BY-NC-ND license (http://creativecommons.org/licenses/by-nc-nd/4.0/) actualize the requests of the individuals, the races where they are chosen must be held decently and results processed precisely.In recent times, the voting systems are not so secure (decisions were not unknown). Rather a Paper based Surveying Framework has three issues (examined underneath). The change in perspective from hand based surveying framework to paper based surveying framework is caused because of populace development and now in present times and well being are essential to such an extent that it has driven another change in perspective from paper to electronic[1]. There is no motivation to stay with paper surveying framework, yet there are numerous security motivations to energize the utilization another electronic surveying framework so as to attract up surveying frameworks to advanced time.

\section{RELATED WORK}

U. Rajkumar et al the unique finger impression shows the most encouraging future in true applications. In light of their uniqueness and consistency after some time, fingerprints have been utilized for recognizable proof and verification reason.

David Friedman et al the Deciding on the Web utilizing ordinary PC's offers just powerless security, yet its primary detriments are in the zones of obscurity and assurance against pressure and additionally vote selling.

Helios Voting et al the Regardless of the asserted advantages of e-casting a ballot activities, more extensive reception of e-casting a ballot components and execution forms is more slow than anticipated. A few specialized, social, and social difficulties ruin generability and appropriateness of evoting

\section{EXISTING METHODOLOGY}

Web casting a ballot might be directed in a different ways,

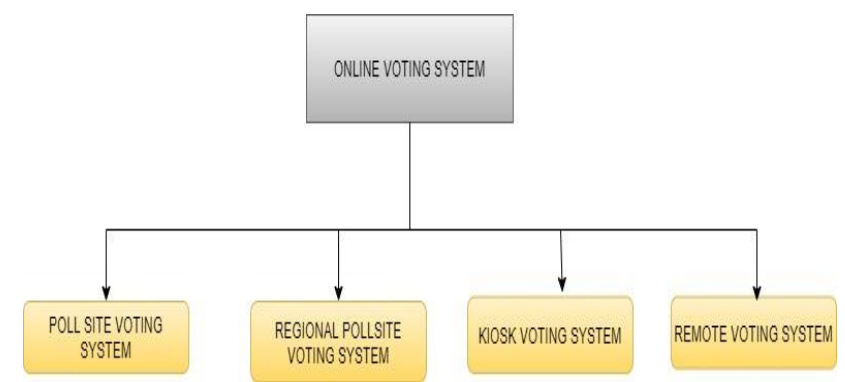

Fig. 1. Different ways of onine voting

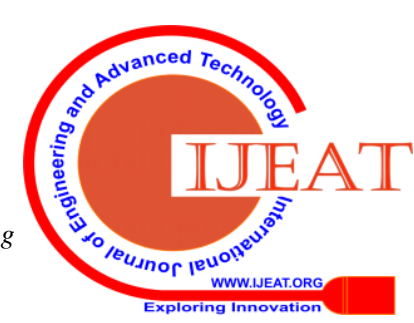


Online voting systems are described [3-5] in different ways based on Fig.1.

A. Survey website web casting a ballot frameworks that expect voters to go to staffed surveying spots and use PCs to cast their votes. The web is utilized to move the voting forms from each surveying spot to incorporated counting places.

B. Provincial survey website web casting a ballot frameworks that permit voters to go to any survey webpage in a specific city or district to make their choice. The framework monitors which voters have just cast their voting forms, and conveys the right voting form paper to every voter dependent on where one lives.

C .Stand web casting a ballot frameworks that permit voters to cast a ballot from PCs in KIOSKs set up by the democratic expert in advantageous areas, for example, post workplaces and shopping centers. The KIOSKs are not observed by survey laborers constantly and may permit casting a ballot over a time of a few days or weeks.

D. Remote frameworks [2] that permit voters to cast a ballot from any PC associated with the web - normally at home or grinding away. Just as by means of PCs, home web casting a ballot could be through computerized TV or even cell phones or games machines. Remote web casting a ballot may be utilized to supplant survey webpage casting a ballot totally, or it may be utilized uniquely for non-attendant balloting. The sensational effect of the web has prompted conversations about the connection among e-democracy and web based democratic. Some early aficionados announced that the web could supplant delegate popular government, empowering everybody to decide on everything and anything at the press of a catch [6]. Such dreams misrepresent the fair procedure. Others have contended that e-voting could lessen expenses and increment turnout by making casting a ballot increasingly helpful.

\section{PROPOSED METHODOLOGY}

\section{A. Level 0: Online Voting System}

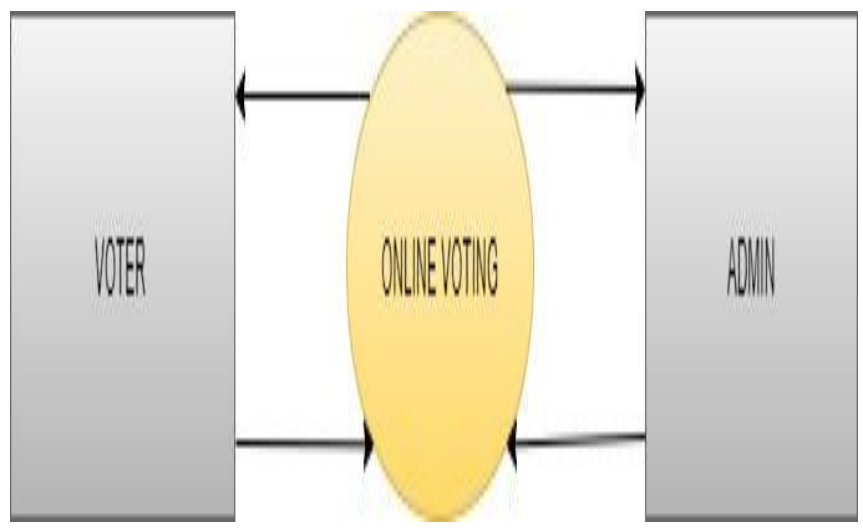

Fig. 2. Online voting system.

Fig. 2 shows that in initial phase the voter login to the login portal on successful authentication based on the aadhaar card location voting portal for their specific location is open portal is opened for specific time and wait for the user to poll their vote. After successful polling portal will close with a response. Admin have separate portal for the login process to check the polling of their votes. Both voter and admin have separate login process at the time of voting.

\section{B. Level 1: Process Of Adding Election, Voters And Candidates}

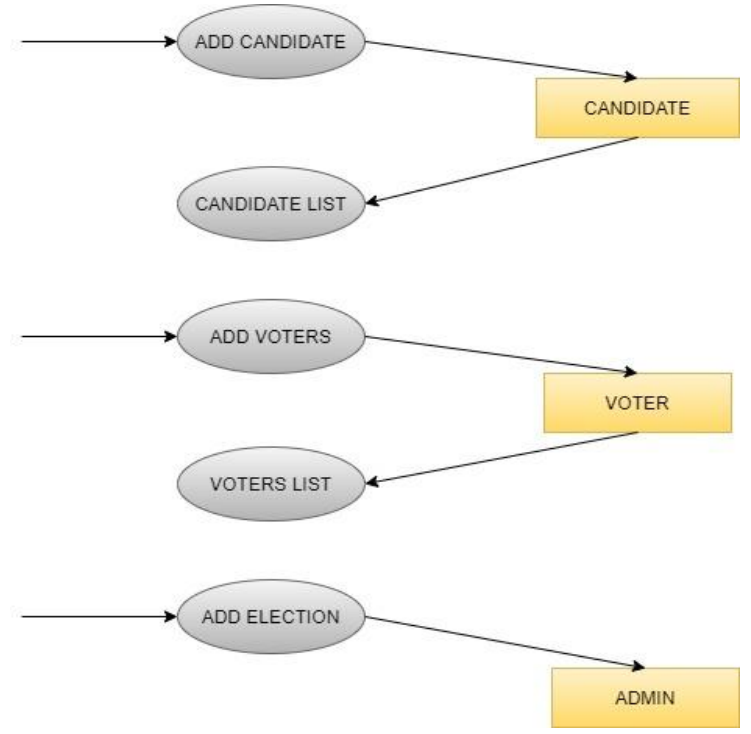

Fig.3. Voters administration process.

Fig. 3 shows that the process of adding election candidate and voters to the portal by administrator.

\section{EXPERIMENTAL WORK}

The newly updated casting of polling voting conventions has two key players: the voting station and the operator of areas. voter (which can be placed at home, in the office or in the extraordinary surveying station or any other device which has the capacity to play confirmation and voting)[6-7].The executive plays out the capacity of voter and up-and-comer enlistment, approval and approval of voter, database and tallying and the outcome.

The fundamental points of interest of the new convention are the accompanying:

1. Public straightforwardness by the chairman (distribution of Voter ID key, and so forth.).

2. Inured to specialized difficulties like interference of access, and so forth, uncomplicated recuperation.

3. Possibility of setup for various democratic models by arrangements and more noteworthy execution.

\section{RESULT}

Table- 1 shows that Performance Analysis by the candidates for a constituency

\begin{tabular}{|c|c|c|c|c|c|}
\hline \multirow[b]{2}{*}{ S. No } & \multirow[b]{2}{*}{$\begin{array}{c}\text { Candidat } \\
\text { e ID } \\
\end{array}$} & \multirow[b]{2}{*}{$\begin{array}{l}\text { No. of } \\
\text { votes }\end{array}$} & \multicolumn{3}{|c|}{ Place } \\
\hline & & & $\frac{\mathfrak{d}}{\mathrm{d}}$ & ָ̃ & 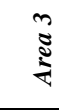 \\
\hline 1 & A & 100 & 36 & 30 & 34 \\
\hline 2 & B & 151 & 78 & 26 & 47 \\
\hline 3 & C & 67 & 10 & 42 & 15 \\
\hline
\end{tabular}

Published By:

Blue Eyes Intelligence Engineering \& Sciences Publication

(C) Copyright: All rights reserved.

Published By:
Blue Eyes Intelligence Engineering
\& Sciences Publication
(C) Copyright: All rights reserved.




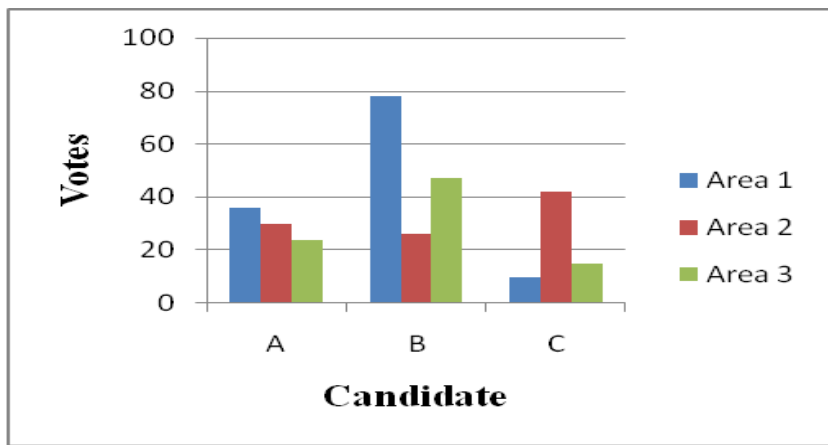

Fig.4. Areawise popularity of each candidate

Fig. 4 shows that candidate $B$ is the winner of the election where candidate B secure overall of 151 votes and scores $20 \%$ higher than candidate A and 26\% higher than candidate.

\section{CONCLUSION}

This proposition empowers a voter to cast his/her vote through web without going to casting a ballot and also enrolling himself/herself for casting a ballot ahead of time, intermediary vote or twofold democratic is preposterous, quick to get to, profoundly secure, simple to keep up all data of casting a ballot, exceptionally proficient and adaptable. The utilizing of organized democratic has the ability to lessen or expel undesirable human blunders. Notwithstanding its unwavering quality, organized democratic can deal with various modalities, and give better adaptability to enormous races.

\section{FUTURE ENHANCEMENT}

In future, This system can be upgraded with SMS questions. That will get the outcome for an hour of checking. To get the Messages we have to register our mobile number in the site.

\section{REFERENCES}

1. Kohno, T., Stubblefield, A., Rubin, A. D., \& Wallach, D. S. (2004, May). Analysis of an electronic voting system. In IEEE Symposium on Security and Privacy, 2004. Proceedings. 2004 (pp. 27-40). IEEE.

2. Rubin, A. D. (2002). Security considerations for remote electronic voting. Communications of the ACM, 45(12), 39-44

3. Kohno, T., Stubblefield, A., Rubin, A. D., \& Wallach, D. S. (2004, May). Analysis of an electronic voting system. In IEEE Symposium on Security and Privacy, 2004. Proceedings. 2004 (pp. 27-40). IEEE.

4. Ansolabehere, S. (2001). Voting: What is, what could be. Available: http://www.vote.caltech.edu/Reports/

5. Sridharan, S. (2013, July). Implementation of authenticated and secure online voting system. In 2013 Fourth International Conference on Computing, Communications and Networking Technologies (ICCCNT) (pp. 1-7). IEEE.

6. Walake, M. A., \& Chavan, M. P. (2015). Efficient Voting system with (2 2) Secret Sharing Based Authentication. (IJC S IT) Interational Journal of Computer Science and Information Technologies, 6(1), 410-412.

7. Agarwal, H., \& Pandey, G. N. (2013, November). Online voting system for India based on AADHAAR ID. In 2013

8. Eleventh International Conference on ICT and Knowledge Engineering (pp. 1-4). IEEE.

\section{AUTHORS PROFILE}

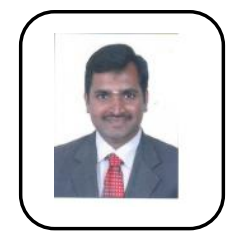

Mr. R. Karthik works as a assistant professor in $\mathrm{Sr}$ Krishna College of Technology in the Department of Computer Science and Engineering with work experience of 13 years. His area of interests are analysis of algorithms and computer networks. His research works include database management system.

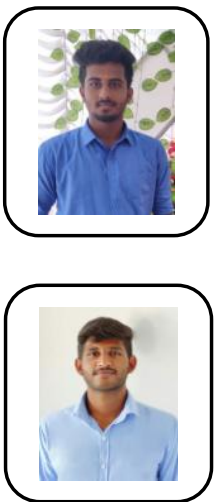

Mr. D. Sabarinaveenkumar, UG student in $\mathrm{Sr}$ Krishna College of Technology in the Department of Computer Science and Engineering.

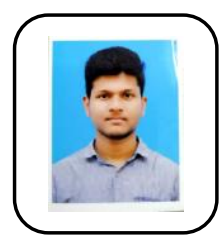

Mr. G. Srinivasan , UG student in Sri Krishna College of Technology in the Department of Computer Science and Engineering. 